\title{
КИТАЙ КАК ПРИОРИТЕТ ВНЕШНЕЙ ПОЛИТИКИ \\ РЕСПУБЛИКИ БЕЛАРУСЬ (1992-2019 ГГ.)
}

\author{
А. В. ТИХОМИРОВ \\ Белорусский государственный университет \\ Минск, Республика Беларусь
}

В статье раскрываются особенности политики Республики Беларусь в отношении Китайской Народной Республики в 1992-2019 гг. Статья обладает научной новизной, поскольку китайский вектор рассматривается в качестве одного из приоритетных направлений внешнеполитической стратегии независимого белорусского государства. Углубление знаний в области формирования и развития отношений с КНР содействует лучшему пониманию особенностей осуществления внешней политики Республики Беларусь в целом и применительно к региону Восточной Азии.

При написании статьи использовались документы, связанные с деятельностью органов государственной власти и управления Республики Беларусь, тексты заявлений и выступлений белорусских политиков, воспоминания белорусских дипломатов. При проведении исследования автор опирался на принцип историзма, использовал общенаучные (анализ, синтез, сравнение, обобщение, дедукция) и специальные исторические методы (историко-генетический, историко-сравнительный структурный подход, системный подход), применил аналитические методики (метод описательного анализа). Действия белорусского государства в отношении Китая оцениваются с позиций неореализма в международных отношениях.

Отмечается, что интерес белорусского руководства к развитию дружественных отношений с КНР проявился практически сразу же с момента выхода Республики Беларусь на международную арену в качестве суверенного и независимого государства и был обусловлен как геополитическими, так и экономическими предпосылками. К концу первого десятилетия XXI в. белорусскокитайские отношения повысились до уровня стратегического партнерства, во втором десятилетии - до уровня доверительного всестороннего стратегического партнерства и взаимовыгодного сотрудничества. Белорусское руководство положительно оценило инициативу «Пояса и пути» и поддерживало ее сопряжение с ЕАЭС. При этом оно стремилось выстраивать отношения с КНР на основе безусловного приоритета национальных интересов белорусского государства, сделав акцент на создании китайско-белорусского индустриального парка «Великий камень».

Ключевые слова: Республика Беларусь; Китайская Народная Республика; внешняя политика; внешнеполитический приоритет; инициатива «Пояса и пути»; торговля; индустриальный парк «Великий камень». 
DOI: https://doi.org/10.33581/2311-9470-2019-7-71-89.

Введение. Современный Китай является одной из значимых величин в мировой политике и экономике, причем эта значимость неуклонно возрастает. Ярким свидетельством служит выдвинутая руководством КНР осенью 2013 г. инициатива создания Экономического пояса Шелкового пути, известная также под названием «Инициатива "Пояса и пути"».

Инициатива получила поддержку многих государств мира. Последовательная установка на формирование многополюсного мира при сохранении свободы действий в международных делах, лежащая в основе внешней политики КНР, начала восприниматься странами Запада, прежде всего США, как вызов. С их стороны все чаще проявляется стремление сдержать Китай посредством комбинации политических, экономических и военных средств.

Республика Беларусь при осуществлении многовекторной внешней политики не может игнорировать процессы, связанные с политикой Китая и его позиционированием на международной арене.

Цель данной статьи заключается в выявлении особенностей политики Беларуси в отношении Китая в 1990-х - 2010-х гг.

Задачи исследования: выявить интересы Беларуси в Китае, раскрыть особенности политики белорусского государства в отношении Китая в 1990-х - 2010-х гг., оценить степень значимости Китая как партнера Беларуси в рассматриваемый временной период.

Хронологические рамки исследования охватывают период с момента установления дипломатических отношений между Республикой Беларусь и КНР в 1992 г. до 2019 г., когда в рамках II форума «Пояса и пути» руководство Беларуси подтвердило курс на сохранение стратегического партнерства с Китаем.

В силу недостаточной проработанности соответствующей проблемы в научном плане данное исследование выстроено преимущественно на информации, почерпнутой из первоисточников: документов из фонда Кабинета министров Республики Беларусь Национального архива Республики Беларусь (НАРБ), официальных заявлений и выступлений Президента Республики Беларусь, документов политических партий, статистики внешней торговли Беларуси, мемуарной литературы (воспоминаний бывших государственных руководителей и дипломатов Республики Беларусь). 
Актуальность исследования заключается в выявлении значимости КНР во внешней политике Республики Беларусь и раскрытии особенностей политики белорусского государства на китайском направлении. Научный анализ, нацеленный на углубление знаний о реализации многовекторной внешней политики Республики Беларусь в конце XX - начале XXI в., представляет интерес для отечественной и зарубежной науки. Публикация поспособствует более предметной оценке особенностей внешней политики Республики Беларусь, позволит глубже раскрыть интересы и формы активности белорусского государства в Восточной Азии.

Методы исследования. При проведении исследования автор опирался на принцип историзма, использовал общенаучные (анализ, синтез, сравнение, обобщение, дедукция) и специальные исторические методы (историко-генетический, историко-сравнительный структурный подход, системный подход), применил аналитические методики (метод описательного анализа). Также он применил метод ивент-анализа, оценивая результаты белорусско-китайского сотрудничества в неореалистической парадигме (раскрывая роль государственных структур в контексте внешней политики Беларуси).

Объектом исследования является внешнеполитическая стратегия Республики Беларусь в отношении Китая.

Предмет исследования - политика белорусского государства в отношении КНР в 1992-2019 гг.

Обзор литературы по теме. В Республике Беларусь и за ее пределами проблематика белорусско-китайских отношений 1990-х 2010-х гг. активно не изучалась. Единственным исследованием, в котором непосредственно рассматривались особенности взаимодействия между Республикой Беларусь и КНР в конце XX - начале XXI в., стала монография В. Мацеля [1].

Следует отметить, что В. Мацель принимал непосредственное участие в процессе налаживания белорусско-китайских связей в качестве сотрудника МИД Республики Беларусь и советника белорусской дипмиссии в КНР. Это способствовало более детальному раскрытию им различных аспектов белорусско-китайских отношений в 19922003 гг. С высокой степенью достоверности В. Мацель отразил динамику белорусско-китайских отношений на рубеже XX и XXI в., увязав активизацию белорусско-китайских связей с политикой Прези- 
дента Республики Беларусь А. Лукашенко. Ценность научного исследования В. Мацеля повышает использование обширного документального материала, в том числе из текущего архива МИД Республики Беларусь. К недостаткам исследования можно отнести чрезмерный оптимизм автора в оценках результатов и перспектив двустороннего сотрудничества между Республикой Беларусь и КНР и его стремление «развести» политические и экономические аспекты сотрудничества.

Проблематику белорусско-китайских отношений была затронута известным белорусским политологом Ю. Шевцовым в исследовании, посвященном геополитическому положению Беларуси в условиях конфликта на Украине в 2014 г. [2]. Ю. Шевцов считал, что сотрудничество с Китаем выгодно для Беларуси (начало сотрудничества он увязывал с контактами двух стран в военно-технической сфере [2, c. 161]).

Он предполагал, что значимость Беларуси для Китая повысится в силу ее географической близости к ЕС и реализации проекта Китайско-белорусского индустриального парка и в среднесрочной перспективе белорусско-китайское взаимодействие приобретет характер стратегического партнерства [2, с. 141, 155, 163]. При этом он высказал мнение, что на белорусскую политику относительно Китая меньше влияют соображения геополитического характера или идеология, чем в других странах Восточной Европы [2, с. 161].

Большой интерес белорусские исследователи проявили к инициативе КНР «Пояс и путь», выдвинутой в 2013 г. В монографии М. Мясниковича, посвященной участию Беларуси в интеграционных проектах на постсоветском пространстве, отмечалось, что «участие Беларуси в проектах Экономического пояса Шелкового пути не должно ограничиваться транзитом через территорию нашей страны китайских грузов и обратно. Требуется создание инфраструктурных и промышленных экспортно ориентированных белорусско-китайских кластеров, в том числе с возможным участием компаний из третьих стран» [3, с. 185].

В. Бельский и Л. Тригубович утверждали, что для Беларуси участие в проекте «Пояс и путь» служит «способом ускорения технологической модернизации экономики, создания высокотехнологичных производств, активизации и значительного расширения экспорта, по- 
вышения эффективности использования транспортно-логистического потенциала территории страны, используемой в качестве ключевого звена Пути» [4, с. 97].

М. Данилович обращала внимание на слабую координацию политики государств - членов ЕАЭС в отношении китайского проекта и сделала вывод, что белорусско-китайское сотрудничество будет и далее развиваться в двустороннем формате с учетом национальных интересов Республики Беларусь [5, с. 239].

В китайском научном сообществе проблематика белорусскокитайских отношений большого интереса не вызывала. В тех случаях, когда исследователи все же оценивали результативность сотрудничества, они обращались исключительно к проблемам взаимодействия в торгово-экономической и инвестиционной сферах. При этом китайские авторы исходили из того, что сотрудничество приносит Беларуси значительную пользу. Такой подход, в частности, характерен для научной статьи профессора Академии общественных наук КНР Чжао Хуэйжун [6].

Исследователи России, других государств - участников СНГ, Западной Европы и Северной Америки проблематику, связанную с политикой Беларуси в отношении Китая, не рассматривали. Исключение составила польская аналитика.

В частности, в монографии Р. Чахора, посвященной внешней политике Республики Беларусь в 1992-2011 гг., в числе прочего рассматривалось развитие белорусско-китайских отношений. Автор указывал, что Китай по своим параметрам идеально подходил на роль партнера Беларуси, а сотрудничество с ним придавало внешней политике белорусского государство реальную многовекторность [7, s. 196]. Также он обращал внимание на повышение значимости Китая во внешней политике Республики Беларусь в условиях ухудшения отношений со странами Запада [7, s. 200].

Однако в большинстве своем белорусские, китайские и иные исследователи концентрировали внимание на практических аспектах сотрудничества, обращаясь, прежде всего, к сфере экономики, и не рассматривали Китай в контексте внешней политики белорусского государства.

Результаты исследования. Интерес белорусского руководства к налаживанию отношений с Китайской Народной Республикой про- 
являлся уже на этапе выхода Республики Беларусь на мировую арену в качестве независимого государства. В январе 1992 г. состоялся визит в КНР белорусской правительственной делегации во главе с Председателем Совета министров Республики Беларусь В. Кебичем. При этом Беларусь стала первым государством - участником СНГ, глава правительства которого был приглашен в Пекин до установления дипломатических отношений ${ }^{1}$.

В мемуарах В. Кебич отмечал: «Военная и экономическая мощь Китая, а вместе с ними и его политический вес на международной арене росли буквально по часам. Установить с ним прочные отношения означало заручиться поддержкой на международной арене, получить своего рода пропуск в клуб избранных... Его поддержка могла стать одним из решающих факторов возрождения белорусской экономики» ${ }^{2}$.

Это высказывание достаточно точно передает суть белорусских интересов в отношении Китая.

Визит положил начало формированию договорно-правовой базы белорусско-китайского сотрудничества. Первыми правовыми актами, подписанными между Республикой Беларусь и КНР, стали соглашения об установлении дипломатических отношений и о торгово-экономическом сотрудничестве (оба соглашения были подписаны 20 января 1992 г.).

Белорусская делегация смогла ознакомиться с общими принципами политики Китая и опытом китайских реформ. В. Кебич встретился с генеральным секретарем ЦК КПК Цзян Цзэминем. Также он посетил первую в КНР специальную экономическую зону в г. Шэньчжэнь и побывал в г. Гуанчжоу, административном центре провинции Гуандун, и в г. Уси провинции Цзянсу.

В целом визит проходил в дружественной атмосфере, хотя по отдельным политическим вопросам возникли разногласия.

В частности, китайские официальные лица без энтузиазма восприняли стремление министра иностранных дел Республики Беларусь П. Кравченко зафиксировать в тексте Соглашения между Республикой Беларусь и Китайской Народной Республикой об установлении дипломатических отношений положение о поддержке Китаем права

\footnotetext{
${ }^{1}$ Кебич В. Ф. Искушение властью : из жизни премьер-министра. Минск : Парадокс, 2008. C. 339 .

${ }^{2}$ Там же. С. 339-340.
} 
Республики Беларусь на этнически белорусские территории, не входящие в ее состав. Китайцы пытались убедить П. Кравченко, что занятая им позиция не соответствует национальным интересам белорусского государства, но в конечном счете приняли требования белоpусов $^{3}$.

В соглашении об установлении дипломатических отношений говорилось, что Беларусь и Китай намерены развивать отношения дружбы и сотрудничества «на основе принципов взаимного уважения и территориальной целостности, взаимного ненападения, невмешательства во внутренние дела друг друга, равенства и взаимной выгоды, а также мирного сосуществования» [1, с. 68]. Республика Беларусь признала КНР «единственным законным правительством, представляющим весь Китай» [1, с. 68].

Летом 1992 г. были установлены связи между Верховным Советом Республики Беларусь и Всекитайским собранием народных представителей (ВСНП).

С 28 августа по 1 сентября 1992 г. КНР впервые посетила белорусская парламентская делегация с целью изучения опыта китайских реформ.

В январе 1993 г. состоялся официальный визит в КНР Председателя Верховного Совета Республики Беларусь С. Шушкевича. Главу белорусского парламента, так же как главу белорусского правительства, тронули теплый прием и оказанные ему почести ${ }^{4}$. Он встретился с премьером Госсовета КНР Ли Пэном и генеральным секретарем ЦК КПК Цзян Цзэминем, побывал в особой экономической зоне Сямэнь в провинции Фуцзянь.

Результатом визита стала концептуальная доработка законопроекта о свободных экономических зонах в Беларуси [1, с. 41].

В ходе визита была достигнута договоренность о проведении регулярных белорусско-китайских межмидовских консультаций и окончательно решился вопрос об открытии Посольства Республики Беларусь в КНР.

Вскоре после визита состоялось назначение Временного поверенного в делах Республики Беларусь в КНР (на эту должность был назначен В. Буря).

\footnotetext{
${ }^{3}$ Кравченко П. К. Беларусь на переломе: дипломатический прорыв в мир : выступления, ст., интервью, беседы, дипломат. док. и переписка. Минск : БИП-С плюс, 2009. С. 58-59.

${ }^{4}$ Шушкевич С. С. Моя жизнь. Крушение и воскрешение СССР. М. : РОССПЭН, 2012. С. 316.
} 
Однако в первой половине 1990-х гг. взаимодействие Беларуси с Китаем оставалось сдержанным. В начале 1994 г. в штате Посольства Республики Беларусь в КНР работало всего лишь четыре дипломата 5 . Глава дипмиссии был вынужден проводить значительную часть времени в здании общежития Посольства Российской Федерации в КНР (на проживание в китайском отеле не было средств) и лично управлял автомобилем. В посольстве отсутствовали телефон и факс ${ }^{6}$.

Позитивные изменения в белорусско-китайских отношениях произошли в 1995 г. Важной вехой в этом плане стал официальный визит в КНР Президента Республики Беларусь А. Лукашенко в январе 1995 г. 17 января 1995 г., в Пекине была подписана Совместная декларация о дальнейшем развитии и углублении сотрудничества между Китайской Народной Республикой и Республикой Беларусь (название документа предопределяло содержание сотрудничества). Весьма важным, с точки зрения руководства Беларуси, являлось намерение китайской стороны уважать избранный путь развития белорусского государства ${ }^{7}$.

27 февраля 1995 г. В. Кузнецов был назначен первым Чрезвычайным и Полномочным Послом Республики Беларусь в КНР. Глава белорусского государства поставил задачу добиться всесторонней интенсификации отношений с дружественным Китаем, сделав акцент на развитии торгово-экономических отношений, увеличении взаимного товарооборота и экспорта белорусских товаров ${ }^{8}$.

В последующие годы президент Беларуси неизменно включал отношения с Китаем в число важных внешнеполитических приоритетов белорусского государства. Акцент делался на экономических аспектах сотрудничества, но иногда (особенно во второй половине 1990-х гг.) начинали фигурировать геополитические соображения. К примеру, в марте 1997 г. президент заявил о возможности создания оси «Минск - Москва - Пекин» в качестве ответа на расширение НАТО на Восток'.

\footnotetext{
${ }^{5}$ Белорусско-китайские отношения в воспоминаниях белорусских послов : к 25-летию установления диплом. отношений / сост. А. Тозик ; под общ. ред. А. А. Тозика. Минск : Звязда, 2017. C. 22.

${ }^{6}$ Там же. С. $16,20$.

${ }^{7}$ Там же. С. 23.

${ }^{8}$ Там же. С. 35.

${ }^{9}$ Волкова М., Караманов Ю. Александр Лукашенко попытался в очередной раз перехватить у Бориса Ельцина интеграционную инициативу // Независим. газ. 1997. 13 марта. С. 1.
} 
29 июля 2000 г. президент Беларуси при встрече с заместителем председателя КНР Ху Цзиньтао заявил: «Я могу констатировать тот факт, что между нашими странами не существует абсолютно никаких расхождений по поводу курса внешней политики, многополярности, противодействия гонке вооружений, единого Китая, а также перспектив сотрудничества» [1, с. 75].

Во второй половине 1990-х гг. стали расширяться белорусскокитайские торговые связи, причем в торговле с Китаем сохранялось положительное сальдо. В 1996 г. белорусский МИД оптимистично расценивал возможности расширения поставок в КНР самосвалов, автомобилей, различных видов станков, продукции радиоэлектронной и оптико-механических отраслей промышленности, контрольно-измерительных приборов ${ }^{10}$.

27 июля 2000 г. Республика Беларусь и КНР подписали Совместное Китайско-Белорусское заявление об укреплении всестороннего сотрудничества в XXI веке. Обе стороны высказали намерение «поднять двусторонние отношения на более высокий уровень в новом веке», выступили в поддержку многополюсного развития мира и невмешательства во внутренние дела суверенных государств, выразили готовность прилагать усилия к установлению нового справедливого и рационального международного политического и экономического порядка [1, с. 172; 174].

В конце XX - начале XXI в. белорусско-китайский политический диалог сохранял предельную степень активности и проходил на самом высоком уровне. Президент Республики Беларусь посещал КНР с визитами в 1997, 2001, 2005, 2008, 2010, 2013, 2015, 2016, 2017 , 2018 и 2019 гг.

В 2000-2010-х гг. Беларусь и Китай устранили диспаритет в организации визитов на высшем государственном уровне. В июле 2001 г. состоялся первый в истории белорусско-китайских отношений официальный визит в Республику Беларусь Председателя КНР Цзян Цзэминя.

В 2007 г. в Беларуси побывал председатель Госсовета (глава правительства) КНР Вэнь Цзябао, в 2008 г. - заместитель председателя Постоянного комитета ВСНП Хань Цидэ, в 2009 г. - вице-премьер

\footnotetext{
${ }^{10} \mathrm{O}$ ходе реализации плана мероприятий по итогам визита Премьера Госсовета КНР Ли Пэна в Республику Беларусь // НА РБ. Ф. 7. Оп. 12. Д. 2407. Л. 14.
} 
Госсовета КНР Хуэй Лянъюй, в 2010 г. - заместитель председателя КНР Си Цзиньпин, в 2011 г. - председатель Постоянного комитета ВСНП У Банго, в 2017 г. - председатель Постоянного комитета ВСНП Чжан Дэцзян. В 2015 г. состоялся государственный визит в Беларусь Председателя КНР Си Цзиньпина.

Беларусь и Китай активно сотрудничали по линии внешнеполитических ведомств, проводили межмидовские консультации по актуальным вопросам международной жизни и двусторонних отношений. Активным и плодотворным было сотрудничество двух стран в ООН.

В 2005 г. было подписано межправительственное Соглашение о принципах сотрудничества между местными исполнительными и распорядительными органами Республики Беларусь и местными правительствами Китайской Народной Республики. Представляется правомерным мнение бывшего Чрезвычайного и Полномочного Посла Республики Беларусь в КНР А. Тозика о том, что указанное соглашение стало «сигналом, стимулом и нормативной базой для развития сотрудничества на региональном уровне» ${ }^{11}$.

В мае 2015 г. Беларусь и КНР подписали договор о дружбе и сотрудничестве, который вступил в силу в сентябре 2016 г.

В декабре 2005 г. было отмечено, что белорусско-китайские отношения «вступили в качественно новый этап, этап всестороннего развития и стратегического сотрудничества» ${ }^{12}$. В 2015 г. для характеристики белорусско-китайских отношений использовался термин «всестороннее стратегическое партнерство», в 2016 г. - «доверительное всестороннее стратегическое партнерство и взаимовыгодное сотрудничество» ${ }^{13}$.

31 августа 2015 г. глава белорусского государства утвердил Директиву № 5, посвященную отношениям с Китаем. В ней подчеркивалось, что развитие всестороннего партнерства с этой страной отвечает долгосрочным интересам Беларуси, укреплению ее международных позиций, способствует обеспечению развития всего спектра белорусско-китайского сотрудничества ${ }^{14}$.

\footnotetext{
${ }^{11}$ Белорусско-китайские отношения в воспоминаниях... С. 131.

${ }^{12}$ Там же. С. 124.

13 О политических отношениях Беларуси и Китая // Посольство Респ.и Беларусь в Кит. Нар. Респ. [Электронный ресурс]. URL : http://china.mfa.gov.by/ru/bilateral/political/ (дата обращения : 01.08.2019).

${ }^{14}$ О развитии двусторонних отношений Республики Беларусь с Китайской Народной Республикой : Директива Президента Респ. Беларусь № 5 // Нац. правовой Интернет-портал 
Директивой устанавливалось, что сотрудничество Беларуси с КНР осуществляется на основе принципов равноправия и взаимной выгоды; применения преимущественно рыночных подходов с учетом интересов Республики Беларусь; приоритетности, долгосрочности реализуемых проектов, последовательности их реализации; прямого и тесного взаимодействия республиканских и местных органов государственного управления с китайской стороной; ответственности субъектов хозяйствования за эффективность реализации проектов взаимовыгодного сотрудничества с КНР ${ }^{15}$.

К основным направлениям белорусско-китайского сотрудничества были отнесены: глубокая и взаимная интеграция отраслей и предприятий; информационно-коммуникационные технологии; формирование совместных исследовательских и научно-практических центров, совместное развитие отраслевой науки; прямое и системное межрегиональное сотрудничество; создание в Республике Беларусь регионального центра китаеведения и взаимодействия с КНР ${ }^{16}$.

Издание директивы свидетельствовало о высокой степени заинтересованности руководства Беларуси в развитии отношений с Китаем, но вместе с тем оно указывало на высокую степень политизации белорусско-китайских отношений.

Между тем результаты, достигнутые в экономической сфере, выглядели неоднозначно. В XXI в. Беларусь и Китай смогли существенно увеличить объем товарооборота. В 2000 г. он составил 197,8 млн долл., в 2005 г. - 715 млн, в 2010 г. - 2159,9 млн, в 2015 г. 3 182,3 млн, в 2018 г. - 3638,1 млн $^{17}$. Однако основу белорусского экспорта в Китай составляли калийные удобрения, в то время как поставки сложнотехнической продукции сократились в сравнении со второй половиной 1990-х гг.

На основе информации белорусских послов в КНР можно сделать вывод о том, что изменение структуры белорусского экспорта стало следствием успешной интеграции КНР в систему мировой экономики на принципах ВТО; успехов Китая в создании собственной

\footnotetext{
Респ. Беларусь [Электронный ресурс]. URL : http://www.pravo.by/document/?guid=3871\&p $0=$ P01500005 (дата обращения : 01.08.2019).

15 Там же.

16 Там же.

${ }^{17}$ Внешняя торговля Республики Беларусь : стат. сб. Минск, 2017. - С. 50, 56; Республика Беларусь в цифрах : стат. справ. Минск, 2019. С. 62.
} 
производственной базы; недостаточной гибкости и инертности белорусских предприятий (особенно связанных с производством машин и станков) ${ }^{18}$.

В 2006 г. в торговле Беларуси с КНР впервые образовалось отрицательное сальдо, причем в последующие годы торговый дисбаланс увеличился. Если в 2010 г. размер отрицательного сальдо в белорусско-китайской торговле превышал 1 млрд долл., то в 2018 г. он составил 2,7 млрд долл. ${ }^{19}$

В 2000-х гг. Китай начал осуществлять инвестиции в белорусскую экономику. При китайском содействии проводилась модернизация минских ТЭЦ-2 и ТЭЦ-5, белорусских цементных заводов, построен отель «Пекин» в Минске. Однако специфика белорусскокитайского кредитно-инвестиционного сотрудничества заключалась в предоставлении китайской стороной связанных кредитов под закупки китайского оборудования, материалов, лицензий и т. П. По мнению А. Тозика, сложившаяся практика инвестиционного сотрудничества привела к росту импорта китайских товаров и услуг для проектов, реализуемых в Беларуси ${ }^{20}$. С этим мнением можно согласиться.

Наиболее масштабным проектом, реализуемым при содействии Китая, стал китайско-белорусский индустриальный парк «Великий камень», под строительство которого было отведено 112,5 кв. км в Смолевичском районе Минской области (в 25 км от Минска) ${ }^{21}$. Соглашение о строительстве парка было подписано в 2011 г., но строительные работы начались в 2015 г.

Главной целью совместного инвестиционного проекта было заявлено развитие высокотехнологичных и конкурентоспособных инновационных производств с высоким экспортным потенциалом передовых технологий. Белорусское правительство создало для резидентов индустриального парка благоприятный инвестиционный климат, гарантированный как национальным законодательством, так и специальными международными соглашениями и обязательствами, предоставило беспрецедентные льготы и преференции, образовало отдель-

\footnotetext{
${ }^{18}$ Белорусско-китайские отношения в воспоминаниях... С. 89-90, 156.

${ }^{19}$ Беларусь в цифрах. 2019. С. 62.

${ }^{20}$ Белорусско-китайские отношения в воспоминаниях... С. 156.

${ }^{21}$ О парке : общ. информ. // Кит.-бел. индустр. парк Великий Камень [Электронный ресурс]. URL : https://industrialpark.by/o-parke/obshhaya-informaciya.html (дата обращения : 22.07. 2019).
} 
ный независимый орган государственного управления для комплексного административного обслуживания по принципу «одного окна» ${ }^{22}$. Отдачу от реализации этого проекта предполагается получить после 2020 г.

В 2010-х гг. активизацию сотрудничества Беларуси с Китаем стала критически оценивать белорусская политическая оппозиция. Так, руководство партии Белорусский народный фронт (БНФ) в феврале 2012 г. негативно оценило факт присутствия китайского капитала в белорусской экономике, обратив внимание на то, что оно приводит к росту внешней задолженности Беларуси, усиливает ее зависимость от Китая, подрывает позиции белорусского бизнеса на внутреннем рынке, ухудшает экологическую ситуацию в стране.

В заявлении руководства БНФ говорилось: «Являясь убежденными сторонниками европейского и евроатлантического выбора Беларуси, мы будем всеми законными способами препятствовать не только исчезновению нашей Родины в составе Евразийского союза, но и ее превращению в “китайский остров в центре Европы”» 23 .

Однако точка зрения белорусского руководства на результативность взаимодействия с Китаем не изменилась. В 2016 и 2017 гг. А. Лукашенко объяснял наличие проблем в реализации совместных проектов с Китаем нерасторопностью белорусского правительства и белорусских предприятий ${ }^{24}$.

В 2018 г. он охарактеризовал сотрудничество с Китаем как благо для Беларуси, в 2019 г. назвал Китай важнейшим стратегическим партнером Беларуси ${ }^{25}$.

\footnotetext{
22 Там же.

${ }^{23}$ Ператварэньне Беларусі ў «кітайскую выспу ў Эўропе» супярэчыць нашым нацыянальным інтарэсам // Партыя БНФ [Электронный ресурс]. 2012. URL : http://narodny.org/?p=1808 (дата обращения : 09.07.2019).

24 Лукашенко А. Г. Обращение с ежегодным Посланием к белорусскому народу и Национальному собранию // Офиц. интернет-портал Президента Респ. Беларусь [Электронный ресурс]. 2016. URL : http://president.gov.by/ru/news_ru/view/aleksandr-lukashenko-21-apreljaobratitsja-s-ezhegodnym-poslaniem-k-belorusskomu-narodu-i-natsionalnomu-13517 (дата обращения: 09.11.2018); Лукашенко А. Г. Послание к белорусскому народу и Национальному собранию // Офиц. интернет-портал Президента Респ. Беларусь [Электронный ресурс]. 2017. URL : http://president.gov.by/ru/news_ru/view/ezhegodnoe-poslanie-k-belorusskomu-narodu-i-natsionaln omu-sobraniju-16059 (дата обращения : 17.02.2019).

25 Лукашенко А. Г. Послание белорусскому народу и Национальному собранию // Офиц. интернет-портал Президента Республики Беларусь [Электронный ресурс]. 2018. - URL : http://president.gov.by/ru/news_ru/view/poslanie-k-belorusskomu-narodu-i-natsionalnomu-sobrani ju-18594 (дата обращения : 10.05.2018); Лукашенко А. Г. Послание белорусскому народу и
} 
Позитивную оценку со стороны официального Минска получила инициатива «Пояса и пути». В апреле 2015 г. на встрече с министром иностранных дел КНР Ван И президент Беларуси заявил, что белорусская сторона готова предоставить свои возможности для реализации данного проекта ${ }^{26}$. В мае 2017 г. он принял участие в I форуме международного сотрудничества «Пояс и путь», отметив, что «при реализации данных концепций не происходит навязывания интересов, торговой экспансии в государства» ${ }^{27}$.

Белорусское руководство выступало за сопряжение «Пояса и пути» с другими интеграционными проектами. В сентябре 2016 г. А. Лукашенко обратил внимание на то, что возможное сопряжение «Пояса и пути» с ЕАЭС и другими интеграционными объединениями на евразийском пространстве созвучно идее «интеграции интеграций», предложенной белорусским руководством осенью 2011 г. $^{28}$

В апреле 2019 г., выступая на II форуме международного сотрудничества «Пояс и путь», президент Беларуси призвал страны участницы инициативы к максимальному расширению экономического сотрудничества и снятию существующих барьеров. В качестве первоочередных мер предлагалось сформировать цифровые транспортные коридоры между Китаем и Европой, упразднить разрешительную систему международных автомобильных перевозок, укрепить взаимосвязь инфраструктур (реконструировать приграничные станции, автомобильные и железные дороги, мосты, создать мультимодальные транспортные узлы $)^{29}$. Таким образом, белорусское руко-

Национальному собранию // Офиц. интернет-портал Президента Респ. Беларусь [Электронный ресурс]. 2019. URL : http://president.gov.by/ru/news_ru/view/poslanie-belorusskomu-narodui-natsionalnomu-sobraniju-2090 (дата обращения : 29.05.2019).

26 Лукашенко А. Г. Встреча с Министром иностранных дел КНР Ван И // Офиц. интернетпортал Президента Респ. Беларусь [Электронный ресурс]. 2015. URL : http://president. gov.by/ru/news_ru/view/vstrecha-s-ministrom-inostrannyx-del-knr-van-i-11179 (дата обращения : 21.01.2018).

27 Лукашенко А. Г. Участие в круглом столе глав государств на форуме «Один пояс и один путь» // Офиц. интернет-портал Президента Респ. Беларусь [Электронный ресурс]. 2017. URL : http://president.gov.by/ru/news_ru/view/uchastie-v-kruglom-stole-glav-gosudarstv-na-forum e-odin-pojas-i-odin-put-16194 (дата обращения : 16.05.2017).

28 Лукашенко А. Г. Выступление перед студентами Пекинского университета // Офиц. интернет-портал Президента Рес. Беларусь [Электронный ресурс]. 2016. URL : http://president. gov.by/ru/news_ru/view/poseschenie-pekinskogo-universiteta-14540 (дата обращения : 15.10. 2017).

${ }^{29}$ Лукашенко А. Г. Участие во II Форуме международного сотрудничества «Пояс и путь» // Офиц. интернет-портал Президента Респ. Беларусь [Электронный ресурс]. 2019. URL : 
водство подтвердило стремление сохранять с Китаем отношения стратегического партнерства.

Обсуждение полученных результатов. В статье на основе принципа историзма и теории политического неореализма проанализированы формы и результаты политики Республики Беларусь в отношении Китайской Народной Республики в 1992-2019 гг.

Проведенное исследование позволяет уточнить отдельные аспекты белорусско-китайского взаимодействия и внешнеполитической стратегии Беларуси. Автор соглашается с мнением Р. Чахора, что развитие взаимодействия с Китаем предопределялось политическими соображениями, выступая в качестве важного элемента многовекторной внешней политики Республики Беларусь. Верным представляется и мнение В. Мацеля относительно того, что существенный импульс укреплению связей с Китаем придала политика Президента Республики Беларусь А. Лукашенко. Вместе с тем необходимо обратить внимание на неоднозначность результатов, достигнутых в процессе развития отношений Беларуси с Китаем, прежде всего в сфере экономики.

\section{Выводы.}

1. Интерес белорусского руководства к развитию дружественных отношений с КНР проявился практически сразу же после выхода Республики Беларусь на международную арену в качестве суверенного и независимого государства. Однако в первой половине 1990-х гг. белорусско-китайское взаимодействие оставалось сдержанным.

2. В середине 1990-х гг. действия белорусского руководства в отношении Китая стали более активными. Интерес к расширению сотрудничества с Китаем был обусловлен как геополитическими, так и экономическими предпосылками. $\mathrm{K}$ концу первого десятилетия XXI в. белорусско-китайские отношения повысились до уровня стратегического партнерства, во втором десятилетии - до уровня доверительного всестороннего стратегического партнерства и взаимовыгодного сотрудничества. В 2015 г. Республика Беларусь и КНР подписали договор о дружбе и партнерстве. Китай вошел в число важнейших внешнеторговых партнеров Беларуси, расширил объем инвестиций в белорусскую экономику. Интенсивность политического диалога меж-

http://president.gov.by/ru/news_ru/view/uchastie-v-mezhdunarodnom-forume-pojas-i-put-20957 (дата обращения : 27.04.2019). 
ду Беларусью и Китаем уступала лишь интенсивности диалога между Беларусью и Россией, причем диалог проходил на самом высоком уровне в дружественной, доверительной атмосфере. Данное обстоятельство давало белорусскому руководству основание положительно оценивать результативность китайского вектора внешней политики Республики Беларусь, хотя в белорусском обществе присутствовали и иные оценки достигнутых результатов.

3. Белорусское руководство положительно оценило инициативу «Пояса и пути», выдвинутую руководством КНР в 2013 г. Соответствующая инициатива рассматривалась в Минске преимущественно в контексте привлечения новых технологий и инвестиций и налаживания с помощью китайских партнеров выпуска товаров, востребованных на мировом рынке. Официальный Минск положительно оценивал процесс сопряжения «Пояса и пути» с ЕАЭС, но при этом выстраивал отношения с КНР на основе безусловного приоритета национальных интересов белорусского государства, сделав акцент на создании китайско-белорусского индустриального парка «Великий камень».

\section{Библиографические ссылки}

1. Мацель В. М. Становление и развитие дружественных белорусско-китайских отношений. Барановичи : Баранов. укрупн. тип., 2004. 190 с.

2. Шевиов Ю. В. Война на Украине : трансформация Европы. М. : РГГУ, 2018. 299 с.

3. Мясникович M. В. Актуальная повестка развития белорусской экономики в условиях интеграции. Минск : Беларус. навука, 2017. 278 с.

4. Бельский В. И., Тригубович Л. Г. Развитие технологического и инновационного сотрудничества Беларуси и Китая в рамках мегапроекта «Экономический пояс Шелкового пути» // Проблемы сопряжения Экономического пояса Шелкового пути и Евразийского экономического союза : материалы Второго белорус.-кит. гуманитар. науч. форума. (15-17 июня 2017 г., г. Минск) / Ин-т экономики НАН Беларуси. Минск : Право и экономика, 2017. 201 с. C. $95-103$.

5. Данилович М. В. Экономический пояс Шелкового пути : особенности реализации проекта на пространстве ЕАЭС // Актуальные проблемы международных отношений и глобального развития : сб. науч. ст. / сост. Е. А. Достанко; Центр междунар. исследований ФМО БГУ. Минск, 2016. Вып. 4. С. 235-239.

6. Чжао Хуэйжун. Чжубай цзинмао гуаньси дэ фачжань юй цяньцзин $=$ Китайско-белорусские торгово-экономические отношения : развитие и перспективы / Хуэйжун Чжао // Оуя цзинцзи = Евразийская экономика. 2016. № 3. С. 85-98 (на кит. яз.).

7. Czachor R. Polityka zagraniczna Republiki Białoruś w latach 1991-2011. Studium politologiczne. Polkowice : Wyd. Dolnośląskiej Wyższej Szkoly Predsiębiorczości i Techniki w Polkowicach, 2011. $351 \mathrm{~s}$. 
Дата поступления статьи: 30.08.2019.

Образец цитирования: Тихомиров $A$. $B$. Китай как приоритет внешней политики Республики Беларусь (1992-2019 гг.) // Актуальные проблемы международных отношений и глобального развития : сб. науч. ст. Минск, 2019. Вып. 7. C. $71-89$.

Автор: Тихомиров Александр Валентинович - кандидат исторических наук, доцент, доцент кафедры международных отношений Белорусского государственного университета; e-mail: tihomirow@list.ru.

\title{
CHINA AS A FOREIGN POLICY PRIORITY OF THE REPUBLIC OF BELARUS (1992-2019) \\ A. V. TSIKHAMIRAU \\ Belarusian state University, Minsk, Republic of Belarus
}

\begin{abstract}
The article dwells on the peculiarities of the policy of the Republic of Belarus towards the People's Republic of China during the period between 1992 and 2019. The article has a scientific novelty, since the Chinese vector is considered to be one of the foremost priorities of independent Belarusian state`s foreign policy strategy.

Improving the knowledge in the field of forming and developing relations with the PRC contributes to a better understanding of the specific characteristics of the implementation of the foreign policy of the Republic of Belarus as a whole and in relation to the East Asian.

While writing the article, the author has used the documents related to the activities of state authorities and administration of the Republic of Belarus, texts of statements and speeches of Belarusian politicians as well as the memories of Belarusian diplomats. In the research the author has drawn on the principle of historicism, used general academic (analysis, synthesis, comparison, synthesis, deduction) and specific historical methods (historical genetic method, comparative historical structural approach, systematic approach), applied analytical techniques (method of descriptive analysis). The actions of the Belarusian state in relation to China are being reviewed from neorealism in international relations.
\end{abstract}


It is noted that the Belarusian leadership took almost an immediate interest in the development of friendly relations with the PRC from the moment of emergence of the Republic of Belarus into the international arena as a sovereign and independent state. The interest in expanding the cooperation with China was profound due to both geopolitical and economic prerequisites. At the beginning of the 21st century Belarus and China expressed their intention to strengthen their full cooperation. By the end of the first decade of the 21 st century Belarus-China relations had risen to the level of a strategic partnership, in the second decade - to the level of a comprehensive strategic partnership, and then to the level of a trusting allround strategic partnership and mutually beneficial cooperation.

The Belarusian leadership appreciated the Belt and Road Initiative and positively assessed the linking process of the Belt and Road Initiative with the EAEU. The official Minsk, however, establishing the relations with the People's Republic of China on the basis of the unconditional priority of national interests of the Belarusian state with a focus on the construction of the China-Belarus Industrial Park «Great Stone».

Key words: Republic of Belarus; People's Republic of China; foreign policy; foreign policy priority; Belt and road initiative; trade; industrial Park «Great stone».

\section{References}

1. Matsel, V. (2004). Stanovljenije i razvitije druzhestvennyh belorussko-kitajskih otnoshenij [Formation and development of friendly Belarusian-Chinese relations]. Baranovichi, Baranovichi integrated printing. 190 p. (In Russ.).

2. Shevtsov, J. (2018). Vojna na Ukraine: Transformatsija Evropy [War in Ukraine: Transformation of Europe]. M., RGGU, 299 p. (In Russ.).

3. Miasnikovich, M. (2017). Aktualnaja povestka razvitija belorusskoj ekonomiki v uslovijah intrgratsii [The current agenda for the development of the Belarusian economy in terms of integration]. Minsk : Belarus. nauka, 278 p. (In Russ.).

4. Bielskij, V., Trigubovich, L. (2017). Razvitije tekhnologicheskogo i innovatsionnogo sotrudnichestva Belarusi I Kitaja v ramkah megaprojekta "Ekonomicheskij pojas Sholkovogo puti" [Economic zone of the Silk road, especially the implementation of the project in the Eurasian economic Union] In: Problems of pairing the Silk road Economic Belt and the Eurasian Economic Union: Materials of the Second Belarusian-Chinese humanitarian scientific forum (June 15-17, 2017) / Inst. of economics. Minsk : Pravo i ekonomika, p. 95-103. (In Russ.).

5. Danilovich, M. (2016). Ekonomicheskij pojas Shelkovogo puti : osobennosti realizatsii projekta na prostranstve EAES [The Economic Belt of the Silk Road: Features of the project on the space of 
the EAEU]. In: Actual problems of international relations and global development : collection of scientific papers. Minsk, Vol. 4, p. 235-239. (In Russ.).

6. Zhao Huajun (2016). Jubei cinma guanxi de fajar yu cancan $=$ China - Belarus trade and economic relations : development and prospects In: Oa Jinji = Eurasian economy, N3, p. 85-98. (In Chin.).

7. Czachor, R. (2011). Polityka zagraniczna Republiki Białoruś w latach 1991-2011. Studium politologiczne [The Foreign Policy of the Republic of Belarus in 1991-2011. Political science studies]. Polkowice: Wyd. Dolnośląskiej Wyższej Szkoly Predsiębiorczości i Techniki w Polkowicach, 351 p. (In Pol.).

For citation: Tsikhamirau, A. (2019). China as a Foreign Policy priority of the Republic of Belarus (1992-2019). In: Actual problems of international relations and global development : collection of scientific papers. Minsk, Vol. 7, p. 71-89.

About author: Tsikhamirau Aliaksandr - Candidate of Historical Sciences, Associate Professor, Department of International Relations, Belarusian State University; e-mail: tihomirow@list.ru.

Received: 30.08 .2019 . 